\title{
Parathyroid Hormone Status in Patients with End Stage Renal Disease on Maintenance Haemodialysis
}

\author{
SAJJAD SM ${ }^{\mathrm{a}}$, ZAMAN YA ${ }^{\mathrm{b}}$, RAHIM MA ${ }^{\mathrm{c}}$, MAHMUD A ${ }^{\mathrm{a}}$, HAQUE WMM ${ }^{\mathrm{d}}$, UDDIN KN ${ }^{\mathrm{e}}$
}

\begin{abstract}
Objective: To evaluate parathyroid hormone (PTH) status among end stage renal disease (ESRD) patients on maintenance haemodialysis (MHD).

Methodology: This descriptive cross-sectional study was done in the Department of Nephrology, BIRDEM General Hospital, Dhaka, from April to September 2011.

Results: A total of 50 patients were included in this study with a 3:2 male predominance. Mean age was 54.6 (range 34-76) years. Mean duration of ESRD was 3.73 years. All the patients were diabetic and other common co-morbidities were hypertension (76\%), dyslipidaemia (56\%), ischaemic heart disease (48\%) and stroke (12\%). They were receiving calcium (72\%), vitamin D (40\%), both calcium and vitamin D (38\%) supplementation and $20 \%$ were not on any medication for treatment of chronic kidney disease mineral bone disorder (CKD-MBD). Mean pre-dialysis values of urea and creatinine were $30.28 \mathrm{mg} / \mathrm{dl}$ and $8.67 \mathrm{mg} / \mathrm{dl}$ respectively. Mean ( \pm SD) serum level of calcium, phosphate and PTH
\end{abstract}

Introduction

The management of abnormal calcium with phosphate metabolism and hyperparathyroidism in patients with chronic kidney disease (CKD) is a common problem. The bone mineral metabolism abnormalities that occur in renal disease are now encompassed in the term chronic kidney disease mineral bone disorder (CKDMBD). ${ }^{1}$ The major disorders can be classified into those associated with high bone turnover and high

a. Dr. Sarker Mohammad Sajjad, MRCP (UK), Dr. Arif Mahmud, MBBS, SMO, GHPD, BIRDEM.

b. Dr. Yasmin Ara Zaman, MBBS, HMO, Dermatology, BIRDEM.

c. Dr. Muhammad Abdur Rahim, FCPS (Medicine), Registrar, Internal Medicine, BIRDEM.

d. Dr. Wasim Md Mohosinul Haque, FCPS (Medicine), Associate Professor, Nephrology, BIRDEM.

e. Prof. Khwaja Nazim Uddin, FCPS (Medicine), Head, Internal Medicine, BIRDEM.

Address of correspondence: Dr. Sarker Mohammad Sajjad, MRCP (UK), SMO, GHPD, BIRDEM. Email: sajjadsarker450 @gmail.com.

Received: April 07, 2013 Accepted: December 31, 2013 were $8.32( \pm 1.26) \mathrm{mg} / \mathrm{dl}, 4.42( \pm 1.54) \mathrm{mg} / \mathrm{dl}$ and $125.45 \pm 117.71 \mathrm{pg} / \mathrm{ml}$ respectively. In $76 \%$ of the study subjects, PTH level was above normal. Significant difference $(P=<0.05)$ in PTH levels was observed among patients with and without any medication for prevention of CKD-MBD but the levels were within the acceptable range. Serum calcium level in the study subjects had significant positive relationship with serum PTH level. It was also observed that PTH level had significant negative relationship with phosphate level.

Conclusion: PTH level was higher in ESRD patients on MHD specially those who were not on any medication than those who took calcium, vitamin D or both but it was still within the acceptable reference range. In such patients, serum calcium, phosphate and PTH levels should be monitored periodically.

Key words: end stage renal disease, haemodialysis, parathyroid hormone.

(Birdem Med J 2014; 4(1):13-17)

parathyroid hormone (PTH) levels (including osteitis fibrosa, the hallmark lesion of secondary hyperparathyroidism and mixed lesion) and low bone turnover and low or normal PTH levels (osteomalacia and adynamic bone disease). ${ }^{2}$

In CKD, decreased kidney function results in reduced phosphate excretion and consequent phosphate retention which in turn suppresses calcitriol (dihydroxy vitamin $\mathrm{D}_{3}$ ) production accompanied by decreased calcitriol production by reduced kidney mass and ultimately this decreased calcitriol causes reduced calcium absorption from the gastrointestinal tract resulting in hypocalcemia. ${ }^{3,4}$ Hypocalcemia and elevated serum phosphorus levels stimulate the production of PTH and the proliferation of parathyroid cells resulting in secondary hyperparathyroidism. ${ }^{5}$

Hyperparathyroidism has been associated with abnormal bone histology, bone pain, and fractures. ${ }^{6,7}$ Moreover, elevated PTH levels and impaired mineral metabolism seems to be associated with vascular calcification. ${ }^{8}$ Calcification of cardiac muscle and 
coronary vasculature may lead to arrhythmia, left ventricular dysfunction, ischemia, congestive heart failure, and death. ${ }^{9}$ Elevated phosphorus and calciumphosphorus product have also been linked to increased mortality among patients on dialysis. ${ }^{10-14}$

Elevated phosphate levels may hasten the loss of kidney function, possibly via calcium-phosphorus precipitation. Abnormal serum calcium, phosphate and PTH level have been associated with mortality in dialysis patients and are important in the strategy of controlling all aspects of CKD-MBD. A large number of treatment options are now available: diet, calcium, calcium content of the dialysate, phosphate binders, vitamin D, calcimimetics and parathyroidectomy. ${ }^{11,14}$ Moreover excessive calcium supplements are associated with an increased risk of myocardial infarction. ${ }^{15,16}$ So, such patients need treatment to correct abnormal calcium metabolism and periodic monitoring to avoid adverse events. In this study, we have tried to evaluate PTH level in ESRD patients on MHD and its relation with various treatment modalities.

\section{Methods}

This descriptive cross-sectional study was carried out to evaluate 50 subjects of ESRD on MHD in the Department of Nephrology, Bangladesh Institute of Research and Rehabilitation in Diabetic, Endocrine and Metabolic Disorder (BIRDEM) from April 2011 to September 2011. Patients receiving peritoneal dialysis, acute kidney injury (AKI), AKI on CKD and patients with primary parathyroid disorder or disorders of calcium and phosphate metabolism were excluded from the study. The aims of the study were to describe PTH status of ESRD patient on MHD, to compare the PTH level in ESRD patients who were on different treatment modalities for CKD-MBD, to find out any difference of PTH level in different management groups and to describe the relationship of PTH with calcium, vitamin $\mathrm{D}$ and combined calcium and vitamin $\mathrm{D}$ supplementation in ESRD patient on MHD.

Prior to the commencement of this study, the research protocol was approved by Bangladesh College of Physicians and Surgeons. The objectives of this study along with risks and benefit were fully explained to the patients in easily understandable local language and then informed written consent was taken from each patient. It was assured that all information and records would be kept confidential and the procedure would be helpful for both the physician and the patient in making rational approach of the case management. Then the relevant data were collected in a pre-designed structured data collection sheets from the patient and hospital records.

All the relevant collected data were compiled on a master chart first. Then organized by using scientific calculation and standard statistical formulas, percentage was calculated to find out the proportion of the findings. Further statistical analyses of the results were done by computer software device as statistical packages for social scientist (SPSS) version 15 . The results were presented in tables and figures. For significant of differences t-test, correlation test were applied. A 'p' value of $<0.05$ was considered as significant.

\section{Results}

Total number of patients was 50 , male were 30 , female 20. Mean age was $54.6 \pm 10.4$ (range 34-76) years. Majority (60\%) of them were in the age group of 41-50 years followed by $32 \%$ in 40 years or less and $8 \%$ above 50 years. The mean duration of ESRD was $3.73 \pm 2.94$ (range 1-8) years. All the patients were diabetic and other common co-morbidities are shown in Table-I.

\section{Table I}

Co-morbid condition of the study subjects $(n=50)$

\begin{tabular}{lcc} 
Co-morbid conditions & Number & Percentage \\
\hline Diabetes mellitus (DM) & 50 & 100 \\
Hypertension & 38 & 76 \\
Ischaemic heart disease (IHD) & 24 & 48 \\
Dyslipidaemia & 28 & 56 \\
Stroke & 06 & 12 \\
\hline
\end{tabular}

*Multiple responses were elicited

Most (90\%) of the study population were taking calcium (500 mg once daily), vitamin D ( $0.25 \mu \mathrm{gm} /$ day) or both (Table-II). Mean pre-dialysis serum creatinine and urea levels were $8.67 \pm 6.14 \mathrm{mg} / \mathrm{dl}$ and $30.28 \pm 8.46 \mathrm{mg} / \mathrm{dl}$ respectively. Seventy percent of total ESRD subjects had serum calcium level within normal range. Regarding phosphate level, 86\% had serum phosphate level above normal range (Table-III). 
The mean \pm SD serum PTH level in total study subjects was $125.45 \pm 117.71 \mathrm{pg} / \mathrm{ml}$ (Normal level is $7-57 \mathrm{pg} / \mathrm{ml}$ but for ESRD patient the range which recommended in practicing guide line is between $150-300 \mathrm{pg} / \mathrm{ml}$, KDOQI). Significant difference in PTH level was found in different treatment groups (Table-IV). Duration for how long these patients were receiving their medication was very divers in each group.

\section{Table II}

Drug supplementation in the study subjects $(n=50)$

\begin{tabular}{lcccc} 
History & Responses Number Percent- & $\begin{array}{c}\text { P- } \\
\text { value }\end{array}$ & value \\
\hline Calcium & Yes & 36 & 72 & $<.05^{\mathrm{S}}$ \\
Supplementation & No & 14 & 28 & \\
Vitamin D & Yes & 20 & 40 & $<.05^{\mathrm{S}}$ \\
Supplementation & No & 30 & 60 & \\
$\begin{array}{l}\text { Both calcium and } \\
\text { vitamin D }\end{array}$ & Yes & 19 & 38 & $<.05^{\mathrm{S}}$ \\
$\begin{array}{l}\text { Supplementation } \\
\text { History of ingestion }\end{array}$ & No & 31 & 62 & \\
of no medication & No & 10 & 20 & $<.05^{\mathrm{S}}$ \\
\hline
\end{tabular}

*Multiple responses were elicited, $\mathrm{S}=$ significant, $\mathrm{P}$ value reached from $\mathrm{t}$ - test

\section{Table III}

\begin{tabular}{|c|c|c|c|}
\hline \multicolumn{4}{|c|}{$\begin{array}{l}\text { Serum calcium and phosphate level of the study } \\
\text { subjects }(n=50) \text {. }\end{array}$} \\
\hline Variable & Range & $\begin{array}{c}\text { Freque- } \\
\text { ncy }\end{array}$ & $\begin{array}{l}\text { Percent- Mean } \\
\text { age }\end{array}$ \\
\hline \multirow{2}{*}{$\begin{array}{l}\text { Serum calcium } \\
(\mathrm{mg} / \mathrm{dl})\end{array}$} & $\leq 10.50$ & 35 & $708.32 \pm 1.26$ \\
\hline & $\geq 10.51$ & 15 & 30 \\
\hline \multirow{2}{*}{$\begin{array}{l}\text { Serum phosphate } \\
(\mathrm{mg} / \mathrm{dl})\end{array}$} & $\leq 4.34$ & 07 & $144.42 \pm 1.54$ \\
\hline & $\geq 4.35$ & 43 & 86 \\
\hline
\end{tabular}

\section{Table IV}

Serum parathormone level in different treatment groups

Group

Total $(\mathrm{n}=50)$

Calcium Supplementation $(\mathrm{n}=36)$

Vitamin D Supplementation $(\mathrm{n}=20)$

Combined calcium and vitamin

D Supplementation $(\mathrm{n}=19)$

History of ingestion of no medication

for prevention of CKD-MBD $(n=10)$
In correlation analysis, serum parathormone level had negative relationship with phosphate level which was statistically significant. Serum calcium level in the study subjects were positively correlated with serum parathormone level. Relationship of serum parathormone level with serum calcium level was statistically significant. (Table-V) [Figure-1]

\section{Table-V}

Correlation of serum parathormone level with serum calcium and phosphate $(n=50)$.

\begin{tabular}{lcc} 
Correlation traits & r-value & P-value \\
\hline Serum calcium $(\mathrm{mg} / \mathrm{dl})$ & 0.437 & $0.001^{\mathrm{S}}$ \\
Serum phosphate $(\mathrm{mg} / \mathrm{dl})$ & -.0204 & $0.025^{\mathrm{S}}$ \\
\hline r= Correlation coefficient, S= significant, P value reached \\
from t - test
\end{tabular}

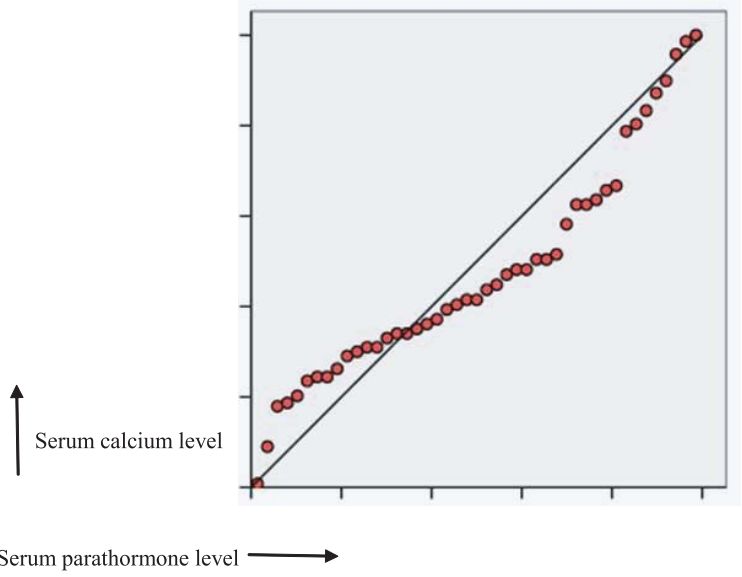

Fig.-1: Scatter diagram showing correlation of serum parathormone with calcium level.

\section{Discussion}

The mean age of our study population was 54.6 years and maximum number of patients was in the age group of 41-50. Sixty percent were male. Similar result was observed in a study at a Centre in Trinidad. ${ }^{17}$ But female predominance was found in other study. ${ }^{18}$

The mean duration of ESRD was 3.73 years. The common co-morbidities were DM, hypertension, IHD, dyslipidemia and stroke. Previous studies revealed most common association of ESRD were DM and hypertension approximately in $75 \%$ of all adult cases. ${ }^{18-21}$ Association of IHD, dyslipidaemia was also reported in $60 \%$ of ESRD cases. $^{18,}$ 22-26 
Mean PTH level in total study subjects was 125.45 pg/ $\mathrm{ml}$. In one study, it was observed that serum PTH level in ESRD patients was $130.86 \pm 58.74 \mathrm{pg} / \mathrm{ml} .{ }^{25}$ Subjects who received no medication had hormone level more than those who received medication for prevention of CKD-MBD. But these levels were still within the range recommended in practicing guide line which is between $150-300 \mathrm{pg} / \mathrm{ml}$ (KDOQI). The present study result revealed that significant difference in parathormone level was observed in those subjects with calcium, vitamin D and combination (calcium with vitamin D) supplementation groups with the group who did not receive any medication for prevention of CKD-MBD. Abboud and Palmer revealed the same results in two separate studies. ${ }^{27,28}$

Mean ( \pm SD) serum level of calcium and phosphate was $8.32( \pm 1.26) \mathrm{mg} / \mathrm{dl}$ and $4.42( \pm 1.54) \mathrm{mg} / \mathrm{dl}$ respectively in the study subjects. Chen observed serum calcium level was about $9.11( \pm 2.26) \mathrm{mg} / \mathrm{dl}$ in ESRD patients. ${ }^{4}$ Rahman et al observed similar result of serum calcium and phosphate level which were $6.49 \pm 0.77 \mathrm{mg} / \mathrm{dl}$ and $6.52 \pm 1.09 \mathrm{mg} / \mathrm{dl}$ respectively. ${ }^{25}$

In correlation analysis, serum PTH level had negative relationship with phosphate level which was statistically significant. Serum calcium level in the study subjects were positively correlated with serum PTH level. Relationship of serum PTH level with serum calcium level was statistically significant. Hanna et al observed comparable result that serum PTH level had negative relationship with phosphate level and positive correlation with calcium level which was statistically significant. ${ }^{23}$

Excess use of calcium salts and calcitriol analogs need to be avoided to prevent adynamic bone disease (ABD). ${ }^{29}$ Some study showed doctors should follow the recommendations given in clinical practice guidelines, always taking into account their personal experience with patients. Furthermore, they must consider the economic impact that their treatment decisions may have. ${ }^{30}$

This study had some limitations. Limited number of patients were evaluated. All the patients were diabetic, whether PTH status is similar in non-diabetic ESRD patients on MHD is not clear.

From the findings of this present study, it can be recommended that physicians should evaluate serum
PTH, calcium and phosphate levels before prescribing vitamin $\mathrm{D}$ and/or calcium supplementation and periodically monitor these levels for those who were already on treatment. However, further studies can be carried out by including large number of study subjects.

\section{References}

1. Tessler FN, Tublin ME. Chronic kidney disease-mineral and bone disorder (CKD-MBD). A new term for a complex approach. N Eng J Med 2009; 351:3-6.

2. Faery MJ, Schneider AB, Stachura ME. The mechanisms of chronic kidney disease-mineral and bone disorder (CKDMBD). ...2009; 19(4):486-92.

3. Sherrard DJ, Hercz G, Pei Y, Maloney NA, Greenwood C, Manuel A, et al. The spectrum of bone disease in endstage renal failure-an evolving disorder. Kidney Int 1993;43:436-42.

4. Hsu CH. Are we mismanaging calcium and phosphate metabolism in renal failure? Am J Kidney Dis 1997;29:641-49.

5. Getekunst R, Hafermann W, Mansky T, Scraba PC. Hyperphosphatemia of chronic kidney disease. Kidney Int 2008; 74(2):148-57.

6. Khosla S, Melton LJ ,Wermers RA, Crowson CS, O’Fallon W, Riggs B. Primary hyperparathyroidism and the risk of fracture: a population-based study. J Bone Miner Res 1999; 14:1700-1707.

7. Atsumi K, Kushida K, Yamazaki K, Shimizu S, Ohmura A, Inoue T. Risk factors for vertebral fractures in renal osteodystrophy. Am J Kidney Dis 1999;33:287-93.

8. Riggs MM, Peterson MG, West SL. Contribution of bone and mineral abnormalities to cardiovascular disease in patients with chronic kidney disease. Chin J Am Soc Nephrol 2008; 3(3):836-43.

9. Chen NX, Moe SM. Vascular calcification in chronic kidney disease. Semin Nephrol 2004; 24(1):61-68.

10. Torres PA, Bore D. Phosphorus and survival, key questions that need answers. J Am Soc Nephrol 2009; 20(2):23436.

11. Lim K, Lu TS, Molostvov G. Treatment of chronic kidney disease-mineral and bone disorder (CKD-MBD). Intern Med 2008; 47(11):989-94.

12. Helen JG. Clinical management of disturbances of calcium and phosphate metabolism in dialysis patients. NDT plus 2009;2 (4): 267-72.

13. Adrogué HJ, Madias NE. Changes in plasma potassium concentration during acute acid-base disturbance. Am J Med 1981; 71 (3): 456-67.

14. Johnson D. CKD screening and management: overview. John Handbook of Chronic Kidney Disease Management. Lippincott Williams and Wilkins. 2011. 32-43. 
15. Ruggenenti P, Perna A, Gherardi G, Gaspari F, Benini R, Remuzzi G. Renal function and requirement for dialysis in chronic nephropathy patients on long-term ramipril: REIN follow-up trial. GruppoItaliano di StudiEpidemiologici in Nefrologia (GISEN). Ramipril Efficacy in Nephropathy. Lancet 1998; 352 (9136): 1252-56.

16. Ruggenenti P, Perna A, Gherardi G, et al. Renoprotective properties of ACE-inhibition in non-diabetic nephropathies with non-nephrotic proteinuria. Lancet 1999; 354 (9176): 359-64.

17. Mungrue K, Ramdial S, Barran A, et al. The epidemiology of end stage renal disease at a centre in Trinidad.West Indian Med J 2011; 60(5):553-56.

18. Van Pottelbergh G, Bartholomeeusen S, Buntinx F, Degryse J. The evolution of renal function and the incidence of end-stage renal disease in patients aged e" 50 years. Nephrol Dial Transplant 2012;27(6):2297-303.

19. Malluche HH, Ritz E, Lang HP. Bone histology in incipient and advanced renal failure. Kidney Int 1976; 9: 355-62.

20. Salusky IB, Ramirez JA, Goodman WG. Disorders of bone and mineral metabolism in chronic renal failure. In: Holiday MA, Barratt TM, Avner ED, eds. Pediatric Nephrology, 2nd edn. Philadelphia, Lippincott Williams Wilkins, 1987; 1287-1304.

21. Hruska KA, Khan N. Parathyroid hormone and calcitonin. In:Massry SG, Glassock RJ, eds. Massry and Glassocks
Textbook of Nephrology, 4th edn. Philadelphia, Lippincott Williams Wilkins, 2000; 205-11.

22. Wenk RE, Efron G. Immulite Intact PTH. Los Angeles: Diagnostic Products Corporation, 2002.31;158-61.

23. Moudgil A, Bagga A. Evaluation and treatment of chronic renal failure. Indian J Pediatr 1999; 66: 241-63.

24. Hanna JD, Foreman JW, Chan JCM. Chronic renal insufficiency in infants and children. Clin Pediatr 1991; 30: 365-84.

25. Rahman MH, Hossain MM, Sultana S, Jamal CY, Karim MA. Correlation of Serum Parathormone Level with Biochemical Parameters in Chronic Renal Failure. Indian Pediatrics 2005; 42:250-54.

26. KasiskeK/DOQI clinical practice guideline for bone metabolism. American Journal of Kidney Diseases 2003; 42 (4): 53.

27. Abboud H, Henrich WL. Clinical practice. Stage IV chronic kidney disease. $N$ Engl J Med 2010; 362(1):56-65.

28. Palmer SC, Navaneethan SD, Craig JC, Johnson DW, Tonelli M, Garg AX, et al. Meta-analysis: erythropoiesisstimulating agents in patients with chronic kidney disease. Ann Intern Med 2010;153:23-33.

29. Jean G. How to manage mineral metabolism disorders in renal failure. Presse Med 2011; 40(11):1043-52.

30. Ramos R, Alcázar R, Otero A, de Francisco AL, del Pino. Economic impact of vitamin D treatment on chronic kidney disease patients. Nefrologia 2011;31(5):528-36. 